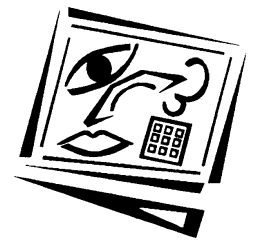

\title{
CoCAR: An online synchronous training model for empowering ICT capacity of teachers of Chinese as a foreign language
}

\author{
Yu-Ju Lan, Kuo-En Chang \\ National Taiwan Normal University \\ Nian-Shing Chen \\ National Sun Yat-sen University
}

\begin{abstract}
In response to the need to cultivate pre-service Chinese as a foreign language (CFL) teachers' information and communication technology (ICT) competency in online synchronous environments, this research adopted a three-stage cyclical model named cooperation-based cognition, action, and reflection (CoCAR). The model was implemented in an 18-week program to prepare pre-service CFL teachers for online synchronous teaching. A qualitative approach was adopted to analyse the collected data. The results demonstrate that the CoCAR model benefits the pedagogical growth of the pre-service CFL teachers, and helps them to make progress in online synchronous teaching activity design and tool usage. The proposed model also creates a positive climate for technological and pedagogic knowledge to overcome some common problems in conventional teacher training programs. The CoCAR model, which emphasises cognition, action, and reflection, is considered suitable for the training of online synchronous teaching skills among CFL teachers, and can be applied to general training programs to enhance the ICT capacity of teachers.
\end{abstract}

\section{Introduction}

To prepare students for the 21st century, teachers must engage them in technology-rich learning activities to improve their learning, and cultivate the competencies needed for creative and innovative use of technology. The universal value of interactive and creative use of technology has influenced teacher training program in many countries, such as the European Union (OECD, 2005), USA (International Society for Technology in Education, 2008; 2009), Taiwan (Taiwanese Ministry of Education, 2008), and Singapore (Singaporean Ministry of Education, 2010). The integration of technology into daily teaching activities to facilitate students' learning and promote creativity is definitely an essential requirement for teachers in this new era. This emphasises that technology enhanced learning is an important competence for teachers of Chinese as a foreign language (CFL). Based on the professional standards for $\mathrm{K}-12$ Chinese language teachers, defined by The Chinese Language Association of SecondaryElementary Schools (CLASS) (Lee, Lin \& Su, 2007) as "technology knowledge and skills" is one area in which CFL teachers are required to demonstrate understanding through the application of technology to support Chinese teaching.

In addition to the general capability of intelligently using information and communication technology (ICT) in traditional Chinese teaching, the skills of online 
synchronous teaching are considered as an essential competence for CFL teachers, because of the global needs in online synchronous language learning. According to British linguist Graddol's argument (2004), the world is becoming increasingly multilingual (See also, Time, 2006). However, many global CFL learners cannot attend face to face CFL classes due to temporal and spatial restrictions (Kan, Lan, Hsiao \& Yang, 2010; Wang \& Chen, 2007). To meet the needs of these CFL learners, computermediated communication technologies make possible meaningful and active communication in a synchronous cyber classroom with "cyber face to face" interaction (Hastie, Chen \& Kuo, 2007, Chen \& Wang, 2008, Wang, Chen \& Levy, 2010a).

There are a number of ways to meet the requirements for communicative interaction (Hampel \& Stickler, 2005) in asynchronous and synchronous modes of online learning. In a synchronous mode, online learning can provide foreign learners with opportunities to communicate and interact with highly competent speakers of the target language. Online synchronous communicative competency is best taught when meaningful interaction is embedded in an authentic context (scenario), with the necessary pedagogical support. Conversely, online teaching using merely asynchronous teaching modes often fails to engage foreign language students in meaningful learning based on the second language acquisition theories proposed by Krashen (1981) and Long (1996) in which successful learning in L2 (learning language as a second language) or FL (learning language as a foreign language) results from authentic, face to face based social interaction. Thus, an urgent need exists for competent and qualified language teachers in online synchronous teaching environments (Chen \& Ko, 2010; Hastie, Hung, Chen \& Kinshuk, 2010; Levy, Wang \& Chen, 2009; Wang, Chen \& Levy, 2010b).

In response to needs in online synchronous teaching, developing a pedagogical model of online professional development supported with empirical evidence is especially important for CFL teachers. Although there is a substantial number of research studies on online language teacher training, few have focused specifically on pre-service CFL teacher training in an online, synchronous cyber classroom environment. Online synchronous language teaching environments are quite different from asynchronous web-based, or traditional face to face settings. Therefore, the training models appropriate to asynchronous or physical environments might not be suitable for synchronous settings. How to train pre-service CFL teachers to apply the synchronous tools in such environments for CFL teaching is still under-investigated. Moreover, while delivering CFL teaching in an online synchronous environment, identifying the kinds of supports needed for the CFL teachers is also an important issue to be dealt with.

In view of the actual needs from both academic and practical perspectives, three questions are raised in this research: (1) What model would be effective in cultivating pre-service CFL teachers' skills for online synchronous teaching environment? (2) How and when will pre-service CFL teachers apply synchronous tools to create synchronous CFL teaching? (3) What kinds of supports are needed for pre-service CFL teachers during a synchronous teaching process?

To answer the first research question, a three-stage professional development model, namely, the cooperation-based cognition, action, and reflection (CoCAR) model will be proposed. This model is in accord with Loughran's argument regarding how knowledge develops (2006), Ricoeur's concept of "practical reason" (1986), and Schön's 
argument about learning action (1987). It aims at increasing pre-service CFL teachers' awareness of gaps between theory and practice, and enhancing their skills in online synchronous CFL teaching via practice, peer evaluation, and self-reflection. Through the complete process, the pre-service CFL teachers are expected to acquire knowledge and have the capacity to deal with emerging situations in an online synchronous teaching environment.

Furthermore, to confirm the efficiency of CoCAR model as well as to answer the other two research questions, a qualitative research investigation was adopted. The model was implemented as an 18-week program from September 2010 to January 2011, with forty-six pre-service CFL teachers participating in the program. During implementation, data were collected and analysed to help evaluate the efficiency of the CoCAR model, to find out the usage status of synchronous tools, and to identify practical issues the teacher faced, based on the online synchronous teaching performance of the pre-service CFL teachers. The following sections describe briefly the theoretical foundations and instructional stages of the CoCAR model. The analytical results from the 18-week implementation program are then presented and discussed.

\section{Online synchronous teacher training model: The cooperation- based cognition, action, and reflection (CoCAR) model}

There are three stages in the proposed model for online synchronous pre-service CFL teachers: cognition, action, and reflection. Developing knowledge, according to Loughran (2006), involves episteme, which is propositional knowledge (Korthagen, Kessel, Koster, Langerwarf \& Wubbels, 2001), and phronesis, a form of practical wisdom (Korthagen et al., 2001). Pre-service CFL teachers require opportunities to experience the differences between cognition and action. Cognition in the proposed model refers to propositional knowledge of a teaching subject (e.g., a foreign language or natural science) and both creative and appropriate use of online synchronous tools. The episteme, in Loughran (2006), consists of general assertions that can be applied to different situations and problems, such as designing teaching plans, providing feedback, deploying learning/teaching strategies, providing timely support, and the capability to use online synchronous tools to support teaching activities. To engage learners in planned synchronous online activities, CFL teachers should be competent in technology, pedagogy, and content knowledge.

Action in the proposed model refers to understanding through experience, whereby pre-service CFL teachers learn from doing and theorise about online synchronous teaching and learning. Action provides opportunities for them to tackle unexpected difficulties encountered in pedagogically challenging situations. Such a teaching and learning process is related to the notion of "actual competency," which was proposed by Jonnaert and Vander Borght (2003). They defined actual competency as "the capacity to successfully manage an unknown situation" (Jonnaert \& Vander Borght, 2003; p. 53). Notably, expert teachers can anticipate problems and transform constraints into resources (Pastré, 2005). Loughran (2006) emphasised the importance of experience, arguing that "learning through experiences" is crucial to the understanding of teaching as something more than a cognitive process. This proposition is congruent to the notion of "knowing-in-action" (Schön, 1987), which refers to types of knowledge that can only be acquired by performing tasks and solving problems. 
In addition, deep understanding about teaching needs to be distilled from reflection. This is a mental process of structuring or restructuring experiences to obtain knowledge or insights (Korthagen, 1999). A pre-service CFL teacher needs opportunities to reflect on what has occurred when solving problems. Additionally, reflection is essential to develop reflective practitioners (Schön, 1987). Through reflective thinking, a pre-service CFL teacher may develop an awareness of her/his behaviour and activity in the online synchronous teaching environment, and consequently develop meta-competency, which in this research is defined as knowledge of and about teaching practice (Guichon, 2009).

Furthermore, it is strongly recommended that the three-stage CFL teacher professional development model is implemented via a cooperation-based approach. According to Ericsson, Krampe and Tesch-Romer (1993), although practice provides learning opportunities, this is far from optimal. Pre-service CFL teachers must learn how to make complex judgments in the online synchronous teaching context. In his study of professional learning by practising teachers, Horn (2005) discovered that groups of teachers sought to improve their teaching skills by talking about incidents, providing peer feedback, and using such information to prepare future teaching tasks. Figure 1 shows the proposed CoCAR model followed by a brief description of model implementation. Solid line arrows in Figure 1 indicate training stages, and dashed line arrows represent the changes in terms of cognition and action that the teachers attempted to make after reflection.

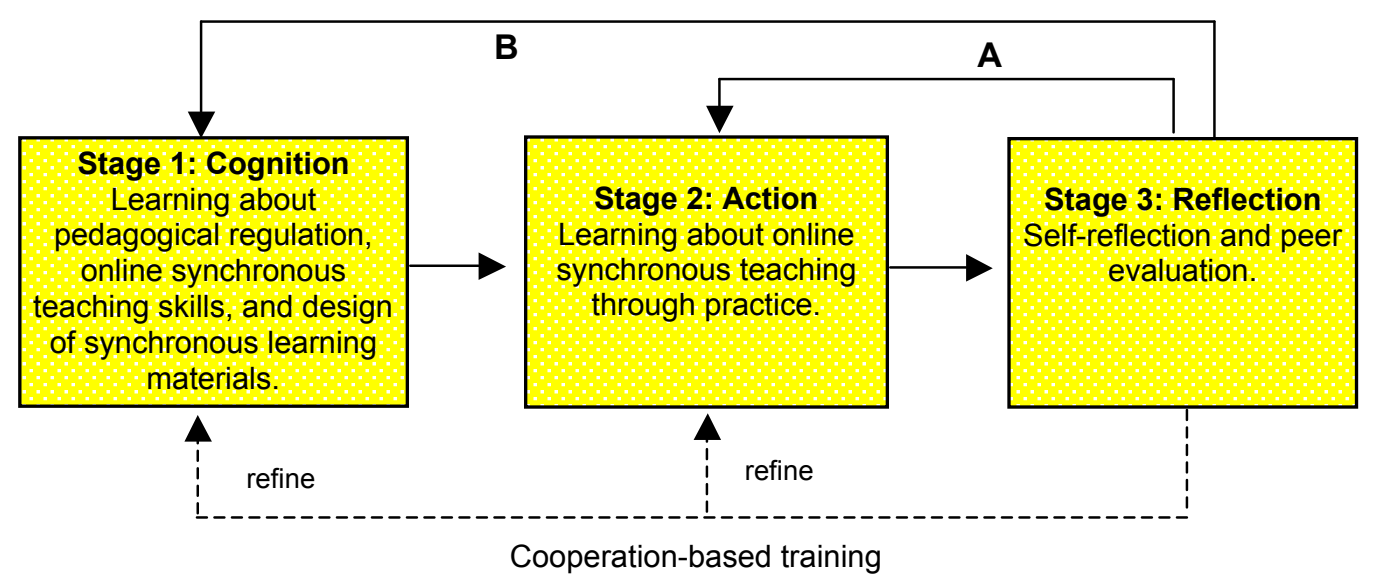

Figure 1: The three-stage CoCAR model for online synchronous CFL teacher training

The three elements - cognition, action, and reflection - are integrated into the proposed CoCAR model because the online synchronous teaching environment is new for the teachers. The learning context provided by this environment is both similar to and different from that of physical teaching environments (Chen \& Wang, 2008). Therefore, it is best that fundamental pedagogical theories and technological know-how for online synchronous teaching (cognition) be taught. Furthermore, learning how to teach in technology-rich synchronous settings by practice (action) is important if pre-service teachers are to be aware of the gaps between theory and reality; and the differences between physical and online synchronous teaching contexts. In addition to cognition and action, pre-service CFL teachers must reflect on their behaviours to shape and construct their own theories and understanding of online synchronous teaching. 
In implementation, the skills for designing synchronous learning activities and distance teaching pedagogy are taught to the pre-service teachers. The subsequent two stages, action and reflection, are implemented in a cyclical manner (solid line arrow A); that is, each online teaching session is followed by self- and peer-evaluation and sharing of experiences. Through actual teaching practices, the pre-service CFL teachers can reflect upon their actions and give feedback to their peers. Self-reflection and peer feedback then serve as a basis for refining the teaching designs and behaviours in the next online synchronous teaching practice. In addition, the trainer/instructor may enhance the pre-service teachers' pedagogical knowledge if they identify further gaps in understanding. The entire instructional process will then restart from the first stage, cognition (solid line arrow B).

\section{Methodology}

\section{Participants}

Students of online synchronous teaching

Forty-six pre-service CFL teachers at National Taiwan Normal University (NTNU) agreed to participate in this research. During the CoCAR implementation process, they played the roles of both online synchronous CFL teachers and learners. None of them had previous experience in the online synchronous teaching environment. After technological operation skills (cognition stage) instruction, participants were organised into small groups of five or six. In total, 8 groups were formed. In addition to the 46 participants, 4 real college-level CFL learners ( 1 from Vietnam, 1 from Canada, and 2 from Bangladesh) participated voluntarily as online learners to enhance the authenticity of the online synchronous teaching practice. However, the 4 volunteers were not included in data analysis for the current research.

\section{Instruments}

Peer-evaluation questionnaire

Items on the peer-evaluation questionnaire were composed on a five-point Likert scale (Appendix A), ranging from 1 "poor" to 5 "excellent". The questionnaire results represent an overall evaluation of an online teaching session. The devised items covered areas such as teaching approaches, leading activities, teaching flow, teaching materials, pace of teaching, students' learning efficiency, time management, and usage of synchronous tools. In addition, the evaluators were tasked to write detailed suggestions for the CFL teachers who practised teaching, which also helped the evaluators to improve their own teaching in the next teaching session. It was compulsory for the participants to answer the questionnaire after each online synchronous teaching session.

\section{Asynchronous discussion forum (ADF)}

The discussion forum was organised in Moodle, a teaching platform for all NTNU students and teachers. All participants were encouraged to post articles that reflected their learning and experience obtained from the practices. They were also encouraged to comment on the teaching, material design, or reflections of other peers. Additionally, this asynchronous discussion forum (ADF) served as a teaching portfolio in providing participants a platform for recording and reflecting upon their online synchronous teaching experiences. However, posting comments on the ADF was optional for the participants. 
Online synchronous teaching observation tables

Two observation tables, "Application of online synchronous tools" (Appendix B) and "Online synchronous teaching activity design" (Appendix C), were utilised to analyse the teaching of the participants during the reflection stage. The former focused on how technical tools in a synchronous cyber classroom were applied to the online synchronous teaching activities, while the latter analysed how student- or teachercentred activities were performed by the CFL teachers when practising teaching an online synchronous CFL class.

Additionally, the two video observation tables were used at the reflection stage. After finishing an online synchronous teaching session, all the participants were asked to view the video and then check the two tables according to the synchronous tool usage statuses or teaching activities. Furthermore, while observing the teaching video, both frequencies and time slots for running each activity or tool usage were also recorded.

\section{Teaching platforms}

Synchronous Learning Management System: Collaborative Cyber Community The Collaborative Cyber Community (3C), as a multi-functional platform for academic and research purposes to hold meetings or exchange opinions. Funded by the National Science Council, it has been upgraded continually by Taiwan's National Sun Yat-Sen University (Wang et al., 2010a). The 3C was used for this research to serve as the online synchronous teaching and learning platform.

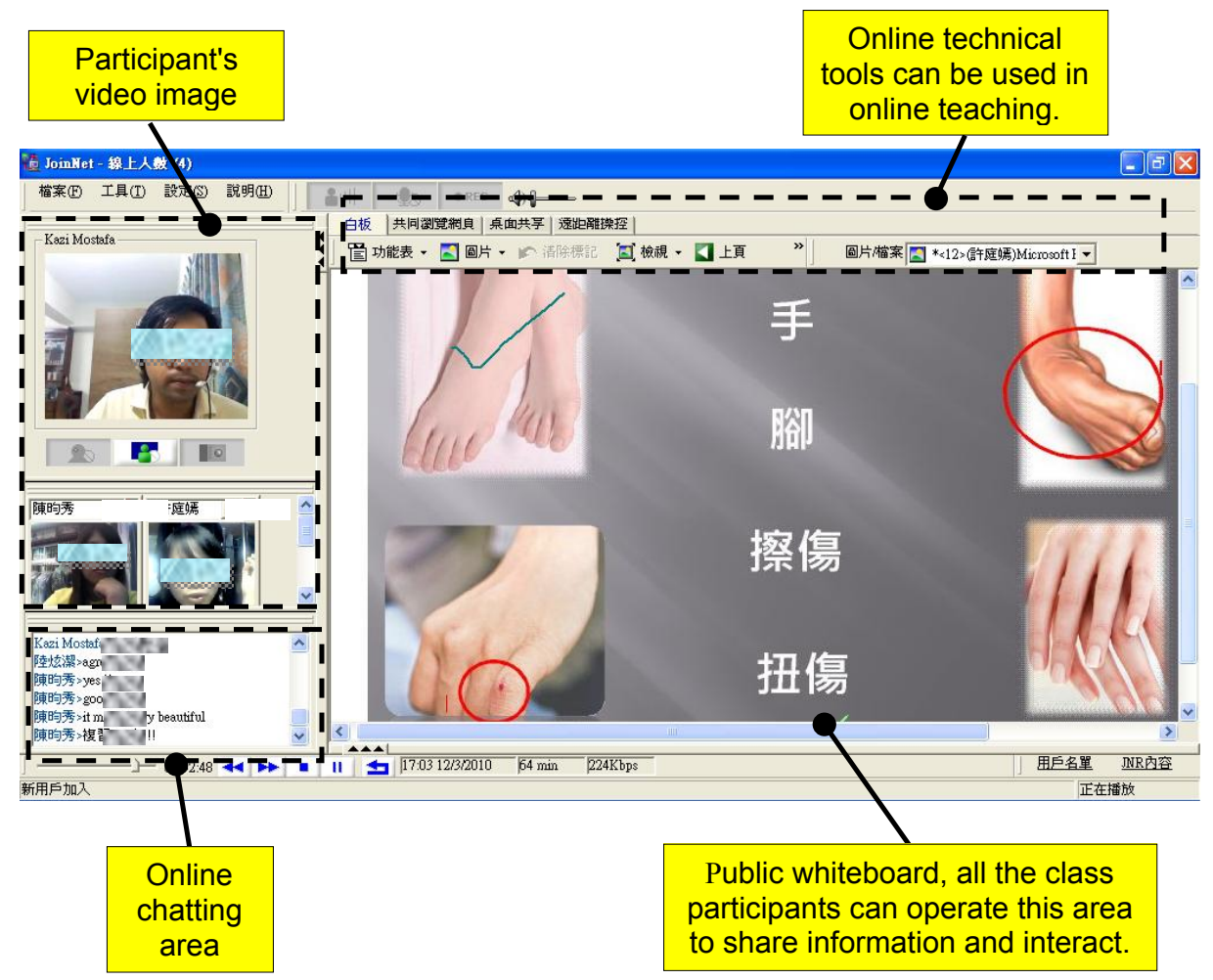

Figure 2: A screen shot of online synchronous CFL teaching in the 3C 
All teaching activities were video recorded. Although the $3 \mathrm{C}$ has both synchronous and asynchronous functions, only the former was adopted, as the focus of this research was to cultivate pre-service CFL teachers' abilities such as managing a synchronous cyber classroom, and creating communicative activities for online synchronous CFL instruction. Figure 2 shows a screen shot of online synchronous CFL teaching via the $3 \mathrm{C}$. The asynchronous function was only used for downloading video recordings.

\section{Procedure: Three-stage implementation of the CoCAR model for preparing pre- service CFL teachers the synchronous teaching skills}

The CoCAR model was implemented in the following sequences.

\section{Stage 1: Cognition}

Stage 1, cognition, a 9-week session that focused on managing an online synchronous teaching environment was conducted. During this stage, online synchronous teaching skills for operating a synchronous cyber classroom, designing of online synchronous learning activities, and distance language learning pedagogy were taught via lectures (physical and online), experience sharing, and online synchronous teaching demonstrations. At the end of this stage, all students were randomly assigned to small groups and then asked to design a ten-minute lesson plan. Whilst one group of the participants taught, other participants were students, and vice versa.

While teaching, an instructor gave immediate feedback to help the pre-service CFL teachers to refine their teaching in the online synchronous teaching environment as well as their design of teaching materials and lesson plans. Such lesson implementation helped the instructors to ensure that each participant knew how to use the synchronous tools in the synchronous cyber classroom and design a lesson plan. In this stage, it gives trainers an opportunity to identify what knowledge pre-service CFL teachers lacked, and also to prepare them for the next stage. This implementation steps are as follows.

Step 1: Introduce synchronous tool usage in the online synchronous teaching environment, synchronous cyber classroom delivery skills, pedagogic regulation, and e-learning material design.

Step 2: Group participants into small groups of 5 or 6 people.

Step 3: Cooperatively design mini teaching plans.

Step 4: Mini teaching plans are implemented.

Step 5: Feedback is given to each group synchronously.

Step 6: Further pedagogical knowledge needed in the online synchronous teaching environment is provided when necessary.

Stages 2 and 3: Action and reflection

These stages were implemented for 8 weeks. The goal of the action stage was to provide the pre-service CFL teachers opportunities to learn how to teach via practice. Participants in a small group designed online synchronous CFL teaching materials cooperatively and practised teaching. Additionally, all activities undertaken by the participants in the action stage were video recorded for subsequent self-reflection and peer evaluation in Stage 3. While teaching, one participant taught and others in the same group were either teaching assistants (TAs) or online learners. The implementation of action stage has the following steps. 
Step 1: Cooperatively design lesson plans and e-materials.

Step 2: Discuss the lesson plans with expert teachers or the instructor.

Step 3: Revise the teaching plan and e-materials based on the discussions in Step 2.

Step 4: Cooperatively practise online synchronous teaching in which one participant played the role of CFL teacher and the others in a same group were learners; the entire teaching procedure will be recorded for later reflection.

Step 5: Reflect on and receive peer evaluations (described in the following section) to enhance one's competency in teaching. Return to Step 1 and begin a new teaching process.

Soon after each session, the professional development process moved on to reflection. All participants watched the teaching video clips and filled out the two observation tables (as shown in Appendices B and C). Participants were also asked to answer a peer-evaluation questionnaire (Appendix A) which allowed pre-service CFL teachers to evaluate the online synchronous teaching of others. This peer-evaluation questionnaire is an overall assessment of online synchronous teaching, including teaching procedures, usage of online synchronous tools, guidance given during online learning activities, tutor-learner and inter-learner interactions, and online community organisation. Additionally, they could also reflect upon their teaching or provide comments to their peers via the asynchronous discussion forum (ADF) if there were additional comments other than those had been provided in peer-evaluation questionnaire. In $\mathrm{ADF}$, the pre-service CFL teachers could discuss difficulties, share opinions like successful teaching and frustration, and report on their own pedagogic development and professional growth.

Note that when implemented, three stages would be run over in each session, which meant that each participant at least had one practice opportunity for acting as an online synchronous teacher. Although the action and reflection stage were repeated eight cycles in this study, each participant had only done the teaching once or twice.

\section{Data collection and analysis}

A qualitative methodology was adopted to evaluate the CoCAR model as well as to answer the research questions. Data, which were collected during the implementation, included teaching videos, observation tables (Appendices $B$ and $C$ ), the peer evaluation questionnaire, and ADF posts. The goal of the analysis was to understand how the participants applied technical tools to the online synchronous CFL teaching, what supports were needed during teaching, and how action and reflection influenced their professional growth. As to the two observation tables, time slots for each kind of tool usage and teaching activities were calculated and compared between different benchmarks that will be discussed below in the Results section. For the peer evaluation questionnaire, the frequencies of all the dimensions were computed. The ADF data were analysed based on the coding approach of grounded theory (Hong, 2011).

Table 1: Multi-data collected during the training

\begin{tabular}{|l|c|}
\hline \multicolumn{1}{|c|}{ Data collected } & Quantity \\
\hline Online synchronous teaching video & 43 \\
\hline Peer evaluation questionnaire & 45 \\
\hline Moodle forum posts (self-reflection) & 26 \\
\hline
\end{tabular}




\section{Results}

Analysis of the online synchronous teaching videos focused on how pre-service CFL teachers used the online synchronous tools in this environment and on their teaching approaches. The two observation tables were used to decode the video data when participants did their peer-evaluation and self-reflection. The table shown in Appendix $B$ focused on what and when synchronous tools were used in the online synchronous teaching environment. The tools in the synchronous cyber classroom comprised a shared whiteboard, desktop sharing, text chatting, remote desktop control, token passing, meeting room setup, voting, and webcam. The other observation table, shown in Appendix C, focused on the teacher-centred and student-centred activities used when practising online synchronous CFL teaching. The analysis of the peer-evaluation questionnaire and ADF posts focused participants' reflections on their own and others' practice teaching. The results of the collected data mentioned above are presented below.

\section{Analysis of online synchronous teaching videos: Coding of the two video observation tables}

In total, 43 online synchronous CFL teaching videos were analysed based on the coding schemes of the video observation tables. Tables 2 and 3 show the results and illustrate how pre-service CFL teachers applied online synchronous tools during practice and what kinds of activities (teacher-centred or student-centred) were adopted in implementing online synchronous CFL teaching.

Table 2: The frequencies and percentages of online synchronous tools used in the cyber classroom

\begin{tabular}{|c|c|c|c|c|c|c|c|c|c|}
\hline \multirow{2}{*}{\multicolumn{2}{|c|}{ Activities }} & \multicolumn{8}{|c|}{ Online tools (percentages of using frequencies) } \\
\hline & & $\begin{array}{l}\text { White } \\
\text { board }\end{array}$ & $\begin{array}{l}\text { Desk- } \\
\text { top } \\
\text { sharing }\end{array}$ & $\begin{array}{l}\text { Text chat } \\
\text { window }\end{array}$ & $\begin{array}{l}\text { Remote } \\
\text { desktop } \\
\text { control }\end{array}$ & $\begin{array}{c}\text { Token } \\
\text { passing }\end{array}$ & $\begin{array}{l}\text { Meeting } \\
\text { setup }\end{array}$ & $\begin{array}{l}\text { Web- } \\
\text { cam }\end{array}$ & Voting \\
\hline \multirow{3}{*}{\multicolumn{2}{|c|}{$\begin{array}{l}\text { Break the ice } \\
\text { Review learning materials } \\
\end{array}$}} & 2.70 & .54 & 4.19 & .00 & .00 & .00 & .95 & .00 \\
\hline & & 2.70 & .14 & .68 & .00 & .00 & .00 & .41 & .27 \\
\hline & & 2.97 & .68 & 1.89 & .00 & .00 & .00 & .27 & .00 \\
\hline \multirow{3}{*}{$\begin{array}{l}\text { Teach } \\
\text { new mat- } \\
\text { erials }\end{array}$} & $\begin{array}{l}\text { Characters / } \\
\text { words }\end{array}$ & 11.89 & 1.22 & 10.14 & .14 & .41 & .41 & 1.22 & .00 \\
\hline & \begin{tabular}{|l|} 
Sentence \\
patterns
\end{tabular} & 10.00 & 1.22 & 9.32 & .14 & .41 & .54 & .95 & .00 \\
\hline & Dialogues & 10.14 & 1.22 & 6.62 & .14 & .54 & .41 & 1.08 & .27 \\
\hline \multicolumn{2}{|c|}{ Assessment } & 3.11 & .68 & 3.78 & .12 & .27 & .41 & .41 & .27 \\
\hline \multicolumn{2}{|c|}{ Homework assignments } & .14 & .00 & .27 & .00 & .14 & .00 & .00 & .00 \\
\hline \multicolumn{2}{|c|}{$\begin{array}{l}\text { Words to say before the } \\
\text { end of the meeting }\end{array}$} & .67 & .25 & 2.03 & .00 & .39 & .12 & .12 & .00 \\
\hline \multicolumn{2}{|c|}{ Summary (\%) } & 44.32 & 5.95 & 38.92 & .54 & 2.16 & 1.89 & 5.41 & .81 \\
\hline
\end{tabular}

According to Table 2, the whiteboard and text chat were the two most used tools. Preservice teachers used the whiteboard to display teaching materials, introduce a new concept, guide interactive practice, generate tutor-learner interaction, and give tests; the first top three situations in which the two most used synchronous tools chosen were teaching new learning materials. Text chat, also favored by the participants, was used to answer questions and record teaching process. Notably, pre-service CFL teachers also used text chat to encourage each other. The desktop sharing tool was 
often used to share video or website resources, but it was seldom used to demonstrate operation of the $3 \mathrm{C}$ platform.

Some tools were only used by a small number of the pre-service CFL teachers. For example, the webcam was used creatively by a few participants to demonstrate pronunciation of specific phonemes, display objects, or present physical movements to engage and motivate learners. Voting was used by two participants only. This tool was used to motivate online learners, guide dialogue practice, and give formative evaluations to elucidate students' online learning. The meeting room setup was also used by two participants to set up new meeting rooms and to group online learners into pairs for pair work. The token passing function was used by four of them to encourage online learners to share their desktop or take the role of activity director. The remote desktop was used by only one, to help online learners operate their computers.

Table 3: Teaching activities adopted by pre-service CFL teachers whilst practising online synchronous teaching

\begin{tabular}{|c|c|c|c|c|c|c|c|c|c|}
\hline \multirow{3}{*}{\multicolumn{2}{|c|}{$\begin{array}{c}\text { Online synchronous } \\
\text { activities }\end{array}$}} & \multicolumn{8}{|c|}{ Teaching approaches (percentage of frequencies) } \\
\hline & & \multicolumn{4}{|c|}{$\begin{array}{l}\text { Teacher as a lecturer } \\
\text { (teacher-centred) }\end{array}$} & \multicolumn{4}{|c|}{$\begin{array}{l}\text { Teacher as a facilitator } \\
\text { (student-centred) }\end{array}$} \\
\hline & & $\begin{array}{l}\text { Presen } \\
\text {-tation }\end{array}$ & $\begin{array}{l}\text { Explan- } \\
\text { ation }\end{array}$ & $\begin{array}{c}\text { App- } \\
\text { ointed } \\
\text { practice }\end{array}$ & $\begin{array}{c}\text { Discuss } \\
\text {-ion }\end{array}$ & Query & $\begin{array}{l}\text { Pair- } \\
\text { ed } \\
\text { work }\end{array}$ & $\begin{array}{l}\text { Task- } \\
\text { based }\end{array}$ & $\begin{array}{l}\text { Role } \\
\text { play }\end{array}$ \\
\hline \multirow{2}{*}{\multicolumn{2}{|c|}{\begin{tabular}{|l|} 
Break the ice \\
$\begin{array}{l}\text { Review learning } \\
\text { materials }\end{array}$
\end{tabular}}} & 1.78 & 1.07 & 1.78 & .36 & 1.07 & .00 & .36 & .00 \\
\hline & & 1.07 & .36 & 2.49 & .71 & 1.07 & .00 & .00 & 1.42 \\
\hline \multicolumn{2}{|c|}{ Motivate students } & 2.49 & .36 & 2.49 & .00 & 1.78 & .00 & .00 & .00 \\
\hline \multirow{3}{*}{$\begin{array}{l}\text { Teach } \\
\text { new } \\
\text { materials }\end{array}$} & $\begin{array}{l}\text { Characters / } \\
\text { words }\end{array}$ & 7.12 & 1.42 & 4.63 & 1.78 & 8.19 & .71 & .71 & 1.42 \\
\hline & $\begin{array}{l}\text { Sentence } \\
\text { patterns }\end{array}$ & 7.47 & 3.20 & 4.27 & 1.07 & 6.05 & 1.07 & .36 & 1.78 \\
\hline & Dialogues & 5.69 & 1.78 & 3.56 & 1.78 & 6.05 & 2.14 & .36 & .71 \\
\hline \multicolumn{2}{|c|}{ Assessment } & 1.07 & 1.07 & 1.78 & 0.36 & .71 & 1.78 & .36 & 1.42 \\
\hline \multicolumn{2}{|c|}{ Homework assignments } & .00 & .00 & .36 & .00 & .00 & .00 & .00 & .00 \\
\hline \multicolumn{2}{|c|}{$\begin{array}{l}\text { Words to say before the } \\
\text { end of the meeting }\end{array}$} & .00 & .00 & .71 & .36 & .36 & .00 & .00 & .00 \\
\hline \multicolumn{2}{|c|}{ Sub-total (\%) } & 26.69 & 9.25 & 22.42 & 6.41 & 17.44 & 8.90 & 2.14 & 6.76 \\
\hline \multicolumn{2}{|c|}{ Grand total (\%) } & \multicolumn{4}{|c|}{64.77} & \multicolumn{4}{|c|}{35.23} \\
\hline
\end{tabular}

Regarding the teaching activities, $64.77 \%$ of activities - presentation, explanation, practice, and discussion - were teacher-guided. Student-centred activities accounted for only $35.23 \%$ (Table 3). The four approaches, query, pair work, task-based teaching, and role play, were used most when teaching new materials and giving formative assessments. However, despite high percentages of teacher-centred activities being coded, the pre-service CFL teachers were gradually progressing towards studentcentred activities as shown in Table 4 . Three benchmarks out of eight practice turns were chosen (the second, fourth, and seventh turn of practising teaching) for analysis of gradual changes of participants' synchronous teaching practices. In comparing the proportions of teacher-centred and student-centred activities, chi-square analysis identified significant differences between the first and third benchmarks $\left(\chi_{(1,1)}^{2}=38.77\right.$, $p<.05)$, demonstrating that student-centred activities were implemented at the end of this study much more than was the case at the beginning of the period. 
Table 4: Percentages of teacher-centred and student-centred activities for the three benchmarks

\begin{tabular}{|l|c|c|c|}
\hline & Benchmark 1 & Benchmark 2 & Benchmark 3 \\
\hline Teacher-centred (\%) & 85.77 & 79.26 & 43.68 \\
\hline Student-centred (\%) & 14.23 & 20.74 & 56.32 \\
\hline
\end{tabular}

The use of synchronous tools in the online synchronous teaching environment was investigated further using the same benchmarks (Table 5). Pre-service CFL teachers tended to use synchronous tools with multi-tendency as the research progressed. Initially (benchmark 1), most participants only used two synchronous tools - the whiteboard and text chat window - for teacher-centred activities. Furthermore, the text chat window was used most to support each other, but seldom used for teaching activities, neither teacher-centred nor student-centred activities. Conversely, participants used synchronous tools in various ways in the last two benchmarks. The whiteboard and text chat window were again used most at benchmark 2. Some participants also used the desktop sharing tool to present interactive materials and videos. The webcam was used to present objects to help online learners understand some particular ideas. The voting tool found at this benchmark was used once for assessments.

Similarly, participants used multiple tools in benchmark 3. The text chat window was used mostly to support each other and to administer assessments as well as query-andanswer activities. The token passing activity, which was found to be used in two different ways: to communicate with group members for teaching contents, and for student-centred activities in which the online learners were given a token to do an oral presentation. The webcam, which was used in an interesting way, was typically used to demonstrate mouth movements while teaching some Chinese sounds that were difficult for CFL learners to pronounce. Based on these results, the participated preservice CFL teachers did make gradual progress in applying synchronous tools in online synchronous teaching practice.

Table 5: Percentages of synchronous tool use based on the three benchmarks

\begin{tabular}{|l|c|c|c|c|c|c|c|c|}
\hline \multirow{2}{*}{ Benchmarks } & \multicolumn{7}{|c|}{ Online tools (percentages of using frequencies) } \\
\cline { 2 - 9 } & $\begin{array}{c}\text { White } \\
\text { board }\end{array}$ & $\begin{array}{c}\text { Desktop } \\
\text { sharing }\end{array}$ & $\begin{array}{c}\text { Text chat } \\
\text { window }\end{array}$ & $\begin{array}{c}\text { Remote } \\
\text { desktop } \\
\text { control }\end{array}$ & $\begin{array}{c}\text { Token } \\
\text { passing }\end{array}$ & $\begin{array}{c}\text { Meeting } \\
\text { setup }\end{array}$ & $\begin{array}{c}\text { Web- } \\
\text { cam }\end{array}$ & Voting \\
\hline Benchmark 1 & 68.97 & .00 & 31.03 & .00 & .00 & .00 & .00 & .00 \\
\hline Benchmark 2 & 61.18 & 9.41 & 23.53 & .00 & .00 & .00 & 4.71 & 1.18 \\
\hline Benchmark 3 & 34.57 & 8.64 & 39.51 & .00 & 7.41 & .00 & 9.88 & .00 \\
\hline
\end{tabular}

\section{Analysis of the peer evaluation questionnaire}

Table 6 shows the mean scores of the 45 peer evaluation questionnaires for online synchronous teaching activities. In addition to commenting on the online synchronous teaching of other peers, participants also identified the areas that could be improved in future teaching. At the beginning of the professional development program, most participants expressed that they encountered many problems in using online synchronous tools (equipment), time control, evaluating the learning efficiency of CFL students, and activity designs. Additionally, many of them revealed that they had poor time control skills, resulting in an unbalanced teaching pace. In terms of synchronous teaching activities, participants suggested that the number of student-centred activities 
should be increased in their online teaching. Participants' awareness of needs in progress in online teaching management and activity delivery enhanced their online teaching skills. The progress is shown in Tables 4 and 5 and Figures 3 and 4.

Table 6: Analysis of the peer evaluation questionnaire

\begin{tabular}{|l|c|l|c|}
\hline \multicolumn{1}{|c|}{ Items } & Mean & \multicolumn{1}{c|}{ Items } & Mean \\
\hline Teaching approaches & 3.60 & Pace of teaching & 3.59 \\
\hline Activity design & 3.49 & Students' learning effects & 3.45 \\
\hline Teaching fluency & 3.59 & Time management & 3.39 \\
\hline Use of teaching materials & 3.69 & Equipment (software/hardware) & 3.28 \\
\hline
\end{tabular}

\section{Analysis of ADF posts}

The ADF postings convey important information about the pre-service teachers' reflection on their practice of online synchronous teaching. In total, the ADF had 26 self-reflective posts. All the posts were analysed based on grounded theory to produce a coding scheme (Hong, 2011). Consequently, these posts were classified as reflections on teaching, peer encouragement, and appreciation. Additionally, each category included several sub-categories, and there were 10 sub-categories in total. Table 7 lists the frequencies and percentages of different categories of posts as well as example posts. Content analysis indicates that pre-service CFL teachers carefully reflected on their teaching and were aware of the gap between planning and reality.

They also understood that they could improve. Many identified problems in online teaching. For example, some stated that the professional preparation program for preservice CFL teachers should be improved. In addition to expressing their lack of competence in online synchronous teaching and the need for additional professional preparation, some expressed pleasure when recognizing their progress. They appreciated online practice opportunities and expressed their appreciation to other group members in co-designing lesson plans and materials as well as providing support during practice. Many posts were encouraging, demonstrating the benefits of peer support and encouragement to their pedagogic knowledge and growth.

\section{Discussion}

The purposes of this research were to provide an evidence-supported synchronous teaching professional development model for pre-service CFL teachers, to investigate the usage status of online synchronous tools in synchronous CFL teaching, and to identify the supports needed during synchronous CFL teaching process.

Based on the results of video recorded data analysis, participants made progress in synchronous tool use according to comparisons of benchmarks. The progress also could be found in online teaching activities. At the start of the CoCAR process, most participants used less synchronous tools for teacher-centred activities. Yet near the end of the course, they made significant progress in implementing more student-centred teaching activities and applied more synchronous tools creatively to support teaching. This outcome is consistent with recommendations by Compton (2009) for education programs for language teachers. Compton (2009) asserted that virtual field experiences and virtual practicum are needed for online teachers to build the complex schema required for effective online language instruction. 
Table 7: Posts on the ADF

\begin{tabular}{|c|c|c|c|}
\hline \multicolumn{2}{|r|}{ Categories } & Frequency & Example \\
\hline \multirow[t]{5}{*}{$\begin{array}{l}\text { Reflection on } \\
\text { teaching } \\
\text { activities and } \\
\text { behaviours } \\
(49.6 \%)\end{array}$} & $\begin{array}{l}\text { Awareness of the } \\
\text { difference between } \\
\text { teaching plans and } \\
\text { real teaching }\end{array}$ & $8.8 \%$ & $\begin{array}{l}\text { Yesterday was my last teaching practice } \\
\text { session. Even though I had observed others } \\
\text { teach and had a plan, I still made many } \\
\text { mistakes. }\end{array}$ \\
\hline & $\begin{array}{l}\text { Struggling with } \\
\text { unknown situations }\end{array}$ & $4.4 \%$ & $\begin{array}{l}\text { I am glad foreign students were attending our } \\
\text { class. However, we did not know their } \\
\text { proficiency in Chinese. We also did not know } \\
\text { whether they know Pinyin or whether they } \\
\text { understand simple Chinese. Therefore, we } \\
\text { needed to modify our material so students } \\
\text { would not be intimidated by the difficult } \\
\text { material. }\end{array}$ \\
\hline & $\begin{array}{l}\text { Reflection upon one's } \\
\text { teaching }\end{array}$ & $16.9 \%$ & $\begin{array}{l}\text { There are still many issues that I need to } \\
\text { consider, such as time control and volume of } \\
\text { vocabulary. I hope I will improve with each } \\
\text { practice session. }\end{array}$ \\
\hline & $\begin{array}{l}\text { Awareness of the } \\
\text { need to improve one's } \\
\text { teaching }\end{array}$ & $8.0 \%$ & $\begin{array}{l}\text { I was not competent enough as a teacher. I } \\
\text { need to improve my teaching fluency and } \\
\text { software operation skills. }\end{array}$ \\
\hline & $\begin{array}{l}\text { Awareness of one's } \\
\text { progress }\end{array}$ & $11.5 \%$ & $\begin{array}{l}\text { Today was my last practice session this } \\
\text { semester. I found that I could overcome my } \\
\text { nervousness. I can also handle the teaching } \\
\text { process. }\end{array}$ \\
\hline \multirow[t]{2}{*}{$\begin{array}{l}\text { Peer encour- } \\
\text { agement and } \\
\text { suggestions } \\
(26.6 \%)\end{array}$} & $\begin{array}{l}\text { Positive words that } \\
\text { encourage oneself or } \\
\text { others }\end{array}$ & $13.3 \%$ & $\begin{array}{l}\text { Even teaching students simple sentence } \\
\text { patterns is somewhat challenging. However, I } \\
\text { believe that after teaching several times I will } \\
\text { be increasingly proficient as a teacher. Let's } \\
\text { work hard together! }\end{array}$ \\
\hline & $\begin{array}{l}\text { Giving suggestions to } \\
\text { oneself or others }\end{array}$ & $13.3 \%$ & $\begin{array}{l}\text { Suggestion for the next teaching group: } \\
\text { "Get a haircut," due to the rich content of this } \\
\text { unit, it is advised to plan the time needed for } \\
\text { each segment; otherwise, you may not finish } \\
\text { teaching the unit, or you may teach too fast } \\
\text { and leave students confused. }\end{array}$ \\
\hline \multirow[t]{3}{*}{$\begin{array}{l}\text { Appreciation } \\
(23.8 \%)\end{array}$} & $\begin{array}{l}\text { Appreciation of } \\
\text { practice opportunities }\end{array}$ & $15.9 \%$ & $\begin{array}{l}\text { I feel this semester is rich and full! I want to } \\
\text { thank the teacher for giving me this } \\
\text { opportunity. I will work hard. I still need } \\
\text { instruction and advice! }\end{array}$ \\
\hline & $\begin{array}{l}\text { Appreciation for } \\
\text { opportunities to learn } \\
\text { from others }\end{array}$ & $3.5 \%$ & $\begin{array}{l}\text { I learned a lot because our teacher asked us to } \\
\text { observe other peers' teaching. We can learn } \\
\text { from others' teacher's teaching methods, } \\
\text { making our teaching diverse. }\end{array}$ \\
\hline & $\begin{array}{l}\text { Appreciation of } \\
\text { support by group } \\
\text { members }\end{array}$ & $4.4 \%$ & $\begin{array}{l}\text { I deeply appreciate the encouragement as } \\
\text { well as immediate supports given by my } \\
\text { group mates when I encountered teaching } \\
\text { problems. }\end{array}$ \\
\hline
\end{tabular}

Moreover, in terms of practice opportunities for pre-service teachers, this research furthers Compton's arguments (2009). The online synchronous teaching context with CFL learners in this research was an authentic practice context rather than a virtual practicum. The online synchronous teaching context reveals problems to pre-service CFL teachers. Consequently, the participants realised that many unpredictable situations would emerge in their future teaching. They also had opportunities to learn 
how to deal with the problems via peer collaboration and personal reflection. This resulted in creative application of synchronous tools for student-centred activities in the online synchronous teaching environment. As argued by Loughran (2006), preservice teachers need opportunities to take risks, generalise about their experiences, and theorise about teaching.

According to Korthagen and Lunenberg (2004), the teacher education paradigm has shifted in four dimensions - practice, personal practical theory, unique contexts, and individual and collaborative learning and their inter-relatedness. Wilson and Stacey (2004), who summarised a number of studies on online professional development, concluded that the principles of online teacher training are a well-structured knowledge base, workplace practice, and inter-staff sharing; these are authentic contexts for practice and opportunities for critical reflection.

The three stages of CoCAR model first provides pre-service teachers the necessary prerequisite knowledge of synchronous CFL teaching, then engages them in learning to teach by practice and reflection cooperatively. Based on the results obtained in this research, it is found that because of opportunities provided for practice and peer evaluations, participants reflected on their teaching and were aware of the gap between knowledge and reality. It benefits the growth of pre-service CFL teachers in pedagogic competency, which includes awareness of differences between actions and plans, and improvements to be made to teaching practices, cooperation skills, and selfreflection abilities. Additionally, because of opportunities for collaborative learning, teaching practice, and peer evaluations, they made gradual but sound progress in designing teaching activities, technical and leadership skills in the online synchronous teaching environment. Through cooperative learning in group practice, a positive climate for pedagogic growth was also created during the development process. As a whole, the three components of the CoCAR model - knowledge, practice, and collaborative learning and reflection via peer evaluation - plus the authentic and unique context (online environment) in which the CoCAR model was implemented are in line with the new paradigms of teacher education in both the traditional and online synchronous teaching context.

The discussion mentioned above answered the first two research questions; they are "what model would be effective in cultivating pre-service CFL teachers the skills needed in synchronous environment?" and "how and when will pre-service CFL teachers apply synchronous tools to create synchronous CFL teaching?" In addition to the discussion about both the usage status of synchronous tools and synchronous teaching activities mentioned above, some interesting phenomena associated with online tool usage were also identified. The text chat window was used for queries and answers as well as a peer support tool. During the practice sessions, participants within the same group usually used this tool to support and encourage their peers who played the role of online CFL teacher. The text chat window thus fosters the positive dependence among group members in cooperative learning. Moreover, the positive inter-peer dependence seems to promote group solidarity as some participants expressed their appreciation of intra-group supports on ADF postings. It also conveys the importance of peer supports during the professional development process for preservice online CFL teachers. Such timely supports and encouragements provided by group members during teaching without interrupting teaching flow are unique in a synchronous environment. Participants' reflections on ADF postings value the interpeers' real time supports and encouragement. Therefore, how to transfer the real time 
supports and encouragements provided by real teaching peers to an automatic support providing scheme via an intelligent chat agent is a worthy issue for further investigation. Furthermore, such an intelligent support providing agent could also help to initiate inter-peer supports, as at the beginning of a training process participants did not know how to.

Regarding the third research question, "what kinds of supports are needed for preservice CFL teachers during synchronous teaching process," the analysis of peer evaluation questionnaires reveal the answers to this question. The most difficult situations encountered by most of the participants during synchronous CFL teaching included the terrible usage of synchronous tools, poor time control, unbalanced teaching pace, too many teacher-centred teaching activities, and lack of experience in trouble shooting. The participants were aware of the needs in making progress to deal with the above problems while doing reflection; however, it was cognitively demanding for them to deal with problems whilst they were conducting lessons. Therefore, both a real time reminder to help them to identify their problems and an intelligent teaching assistant for giving teaching suggestions are needed for pre-service CFL teachers to execute synchronous teaching successfully.

In addition to the findings discussed above, some unexpected phenomena that demand further consideration were also found. Some synchronous tools were used frequently, like whiteboard and text chat window, but some of the tools were used only by a small number of participants. For example, the webcam was not used until some participants identified the difficulties in teaching Chinese tones and pronunciation only via pictures on the shared whiteboard. This is obviously a correct and appropriate application of the tool that could increase teaching efficiency. However, while the affordance of the tool was pointed out via peer-evaluation, not many participants applied the tool. In other words, it was anticipated that through peer-evaluation, participants would learn from others, but it did not happen to all of them. Much research, such as Guichon's study of language teacher training (2009), Colasante's research on physical education pre-service teaching practice (2011), and Loughran's arguments about developing pedagogy of teacher education (2006), have demonstrated the benefits of peer evaluation to the growth of pre-service teachers in terms of technical skills and teaching competency.

However, the evidence found in this research shows that not all participants benefited even though they completed the peer-evaluation questionnaire and the two observation tables. The gap might be caused by participants' autonomy (Lim \& Chai, 2004). According to Holec's definition of learner autonomy (1981), it is the ability to take charge of one's own learning. In other words, leaner autonomy implies accepting responsibility for one's own learning. As shown in Table 1, only 26 ADF posts were posted by some participants. They automatically uploaded their self-reflections and suggestions to others in addition to the required peer evaluation assignments. In fact, these participants were the same teachers who have showed more creative attempts in the online tools use. Similar results could be also found in the analysis of teaching activities design and delivery. Thus, for a trainer of pre-service CFL teachers, how to increase participants' autonomy is a challenge. Furthermore, as to community establishment, situated learning theory may have a potential solution to this challenge (Lave \& Wenger, 1991). How teacher educators could leverage on a core group of autonomous learners to establish a sociocultural climate that fosters ownership and creativity in learning is certainly a worthy issue for further investigation. 
Multiple teaching approaches were identified from the participants' practice teaching. These include direct instruction, total physical response, task-based, and query. However, the implementation steps of every identified approach were different from the approaches used in traditional CFL settings (Brown, 2007; Nunan, 2004). There is a good possibility that those differences were caused by the innate differences between the two environments, physical and synchronous. Therefore, a careful analysis of implementation details for commonly used language teaching approaches in synchronous environments should be conducted in the future to add to the knowledge of synchronous language teaching and teacher professional development. Additionally, articulating general heuristics for adapting a teaching approach from an environment to another, such as from traditional to synchronous, is also an important area that needs further investigations.

\section{Conclusions}

This research aimed to develop a training model for pre-service online synchronous CFL teachers, to investigate the related issues about managing CFL teaching in an online synchronous teaching environment. Based on the results obtained in this research, we conclude that the CoCAR model fulfils the requirements. In addition, some important issues for future research on teachers' online synchronous teaching professional development are also identified. Creating an intelligent support-providing agent to provide timely supports, encouragement, designing real time reminders and technical assistants could help pre-service CFL teachers in developing meta-cognitive knowledge of online synchronous teaching. Intelligent agents could also facilitate the management of the evolution process of a synchronous CFL teaching community.

Online synchronous CFL teacher preparation is an emerging and urgent issue in teachers' professional development for language teachers. We argue that this is a potentially new frontier for teacher education. The analytical findings of this study can offer insights for teacher education institutes to develop appropriate teachers' synchronous teaching professional development models, thereby ushering in a new era for online language teaching.

\section{Acknowledgment}

The authors would like to thank the National Science Council of the Republic of China, Taiwan, for financially supporting this research under Contract Nos. NSC100-2511-S003-018, NSC97-2631-S-003-002, NSC100-2631-S-011-003 and NSC99-2511-S-110-004MY3. The authors also thank the Ministry of Education of the Republic of China, Taiwan, for financially supporting this research under Aim for the Top University Plan.

\section{Appendices}

The Appendices are available from:

http: / / www.ascilite.org.au / ajet/ ajet28/lan-yj-appendices.pdf

Appendix A: Peer evaluation questionnaire on online synchronous CFL teaching activities

Appendix B: Online synchronous CFL teaching observation table - Application of online synchronous tools

Appendix C: Online synchronous CFL teaching observation table - Online synchronous teaching activities design tools 


\section{References}

Brown, H. D. (2007). Principles of language learning and teaching (5th ed). NY: Pearson Education.

Chen, N. S. \& Wang, Y. (2008). Testing principles of language learning in a cyber face-to-face environment. Educational Technology \& Society, 11(3), 97-113. http:// www.ifets.info/journals/11_3/8.pdf

Chen, N. S., \& Ko, L. (2010). An online synchronous test for professional interpreters. Educational Technology E Society, 13(2), 153-165. http:/ / www.ifets.info/journals/13_2/13.pdf

Colasante, M. (2011). Using video annotation to reflect on and evaluate physical education preservice teaching practice. Australasian Journal of Educational Technology, 27(1), 66-88. http: / / www.ascilite.org.au/ajet/ajet27/ colasante.html

Compton, L. K. L. (2009). Preparing language teachers to teach language online: A look at skills, roles, and responsibilities. Computer Assisted Language Learning, 22(1), 73-99. http: / / dx.doi.org/10.1080/09588220802613831

Ericsson, K. A., Krampe, R. T. \& Tesch-Romer, C. (1993). The role of deliberate practice in the acquisition of expert performance. Psychological Review, 100(3), 363-406. http: / / psycnet.apa.org/index.cfm?fa=buy.optionToBuy\&id=1993-40718-001

Graddol, D. (2004). The future of language. Science, 303(5662), 1329-1331. http: / / dx.doi.org/10.1126/ science.1096546

Guichon, N. (2009). Training future language teachers to develop online tutors' competence through reflective analysis. ReCALL, 21(2), 166-185. http: / / dx.doi.org/10.1017/S0958344009000214

Hampel, R. \& Stickler, U. (2005). New skills for new classrooms: Training tutors to teach languages online. Computer Assisted Language Learning, 18(4), 311-326. http: / / dx.doi.org/10.1080/09588220500335455

Hastie, M., Chen, N. S. \& Kuo, Y. H. (2007). Instructional design for best practice in the synchronous cyber classroom. Educational Technology \& Society, 10(4), 281-294. http: / / www.ifets.info/journals/10_4/24.pdf

Hastie, M., Hung, I. C., Chen, N. S. \& Kinshuk. (2010). A blended synchronous learning model for educational international collaboration. Innovations in Education and Teaching International, 47(1), 9-24. http: / / dx.doi.org/10.1080/14703290903525812

Holec, H. (1981). Autonomy and foreign language learning. Oxford: Pergamon.

Hong, H. Y. (2011). An application of grounded theory in e-learning. In Y. T. Sung (Ed.), Research methodology for e-learning (pp. 137-162). Taipei: The High Education Publisher.

Horn, I. S. (2005). Learning on the job: A situated account of teacher learning in high school mathematics departments. Cognition and Instruction, 23(2), 207-236. http: / / dx.doi.org/10.1207/s1532690xci2302_2

International Society for Technology in Education (2008). The ISTE NETS and performance indicators for teachers (NETS $\bullet$ T). [viewed 30 Dec 2008]. http: / / www.iste.org/Libraries / PDFs/NETS_for_Teachers_2008_EN.sflb.ashx

International Society for Technology in Education (2009). The ISTE NETS and performance indicators for administrators (NETS•A). [viewed 15 Dec 2010]. http:/ / www.iste.org/Libraries/PDFs/NETS_for_Administrators_2009_EN.sflb.ashx 
Jonnaert, P. \& Vander Borght, C. (2003). Créer des conditions d'apprentissage. Un cadre deréférence socioconstructiviste pour la formation didactique des enseignants. Bruxelles: De Boeck.

Kan, Y. H., Lan, Y. J., Hsiao, I. Y. T. \& Yang, S. J. H. (2010). A virtual Chinese language class in Second Life: Lessons learnt from a two-month pilot study. Paper presented at The 18th International Conference on Computers in Education (ICCE 2010). November 29-December 3, 2010, Putrajaya, Malaysia. http:/ / www.icce2010.upm.edu.my/papers/c3/ full\%20paper/C3FP57.pdf

Korthagen, F. A. J. (1999). Linking reflection and technical competence in teaching: the logbook as an instrument in teacher education. European Journal of Teacher Education, 22(2/3), 191-207. http: / / dx.doi.org/10.1080/0261976899020191

Korthagen, F. A. J., Kessels, J., Koster, B., Langerwarf, B. \& Wubbels, T. (2001). Linking practice and theory: The pedagogy of realistic teacher education. New Jersey: Lawrence Erlbaum Associates, Publishers.

Korthagen, F. A. J. \& Lunenburg, M. (2004). Links between self-study and teacher education reform. In J. Loughran, M. Hamilton, V. LaBoskey \& T. Russell (Eds.), International handbook of self-study of teaching and teacher education practices (pp. 421-450). London, England: Kluwer Academic Publishers.

Krashen, S. D. (1981). Second language acquisition and second language learning. USA: Pergamon Press.

Lave, J. \& Wenger, E. (1991). Situated learning: Legitimate peripheral participation. NY: Cambridge University Press.

Lee, L. C., Lin, Y. L. \& Su, C. W. (2007). CLASS professional standards for K-12 Chinese language teachers. US: The Ohio State University National East Asian Language Resource Center. http: / / flpubs.osu.edu / catalog_details.cfm?PubKey=287

Levy, M., Wang, Y. \& Chen, N. S. (2009). Developing the skills and techniques for online language teaching: A focus on the process. Innovation in Language Learning and Teaching, 3(1), 17-34. http: / / dx.doi.org/10.1080/17501220802655417

Lim, C. P. \& Chai, C. S. (2004). An activity-theoretical approach to research of ICT integration in Singapore schools: Orienting activities and learner autonomy. Computers \& Education, 43(3), 215-236. http: / / dx.doi.org/10.1016/j.compedu.2003.10.005

Long, M. H. (1996). The role of the linguistic environment in second language acquisition. In W. C. Ritchie \& K. B. Tej (Eds.), Handbook of second language acquisition (pp. 413-468). San Diego: Academic Press.

Loughran, J. (2006). Developing a pedagogy of teacher education. USA: Routledge.

Nunan, D. (2004). Task-based language teaching. UK: Cambridge University Press.

OECD (2005). The definition and selection of key competencies. [viewed 31 Jul 2010]. http: / / www.oecd.org/ pisa/35070367.pdf

Pastré, P. (2005). Genèse et identité. In P. Rabardel \& P. Pastré (Eds.), Modèles du sujet pour la conception. Dialectiques activités développement. Toulouse: Octarès, 231-260.

Ricoeur, P. (1986). Du texte à l'action. Paris: Le Seuil.

Schön, D. (1987). Educating the reflective practitioner. Jossey-Bass: San Francisco. 
Singaporean Ministry of Education (2010). Nurturing our young for the future - Competencies for the 21st century. [viewed 10 May 2010; not found 5 Aug 2012].

http: / / www.moe.gov.sg/committee-of-supply-debate/ files/ nurturing-our-young.pdf

Taiwanese Ministry of Education (2008). White paper on K-12 information and computer education. (In Chinese) [viewed 10 Oct 2008].

http: / / www.edu.tw/files/site_content/B0010/97-100year.pdf

Time (2006). Get ahead, learn Mandarin: China's economic rise means the world has a new second language - and it isn't English. [viewed 20 Oct 2010; not found 5 Aug 2012]. http: / / www.time.com/time/asia / covers/501060626/story.html

Wang, Y. \& Chen, N. S. (2007). Online synchronous language learning: SLMS over the Internet. Innovate, 3(3). [viewed 20 Jan 2012]. http:/ / www.innovateonline.info/ pdf/vol3_issue3 / Online_Synchronous_Language_Learning__SLMS_over_the_Internet.pdf

Wang, Y., Chen, N. S. \& Levy, M. (2010a). The design and implementation of a holistic training model for language teacher education in a cyber face-to-face learning environment. Computers \& Education, 55(2), 777-788. http:/ / dx.doi.org/10.1016/j.compedu.2010.03.010

Wang, Y., Chen, N. S. \& Levy, M. (2010b). Teacher training in a synchronous cyber face-to-face classroom: Characterizing and supporting the online teachers' learning process. Computer Assisted Language Learning, 23(4), 277-293. http:/ / dx.doi.org/10.1080/09588221.2010.493523

Wilson, G. \& Stacey, E. (2004). Online interaction impacts on learning: Teaching the teachers to teach online. Australasian Journal of Educational Technology, 20(1), 33-48. http:/ / www.ascilite.org.au/ajet/ajet20/wilson.html

Authors: Yu-Ju Lan

National Taiwan Normal University, Taiwan

Email: yujulan@gmail.com Web: http:/ / www2.ntnu.edu.tw/en/

Kuo-En Chang

National Taiwan Normal University, Taiwan

Email: kchang@ice.ntnu.edu.tw Web: http: / / www2.ntnu.edu.tw/en/

Nian-Shing Chen (corresponding author)

National Sun Yat-sen University, Taiwan

Email: nschen@mis.nsysu.edu.tw Web: http:/ / epage.mis.nsysu.edu.tw /

Please cite as: Lan, Y.-J., Chang, K.-E. \& Chen, N.-S. (2012). CoCAR: An online synchronous training model for empowering ICT capacity of teachers of Chinese as a foreign language. In C. P. Lim \& C. S. Chai (Eds), Virtual worlds in tertiary education: An Australasian perspective. Australasian Journal of Educational Technology, 28(Special issue, 6), 1020-1038. http: / / www.ascilite.org.au / ajet/ajet28/lan-yj.html 